\title{
Explaining of wisdom based on philosophical mind, social perspective- taking and self-restraint in student
}

\author{
Mina Cheraghzadeh ${ }^{1}$, Rasool KordNoghabi ${ }^{*}$ \\ 1. MA in Educational Psychology, Bu-Ali Sina University, Hamedan, Iran \\ 2. Associate Professor, Department of Psychology, Bu-Ali Sina University, Hamedan, Iran
}

Recieved: 27 Dec. 2018

Revised: 14 Jan. 2020

Accepted: 16 Jan. 2020

\section{Keywords}

Wisdom

Philosophical mentality

Social perspective-taking

Self-restraint

\section{Corresponding author}

Rasool KordNoghabi, Department of Psychology, Faculty of Economic and Social Science, Bu-Ali Sina University, Hamedan, Iran

Email: Rkordnoghabi@gmail.com

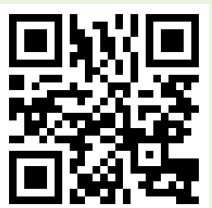

doi.org/10.30699/icss.22.2.1

\section{Abstract}

Introduction: Wisdom is known as the highest stage of cognitive transformation and the highest level of personality transformation. Various factors such as philosophical mentality as a kind of deep thinking in life affairs, social perspective-taking as an understanding of the views of others', and self-restraint that involve personal control about the emotions affect wisdom. The purpose of this study was to highlight wisdom based on philosophical mentality, social perspective-taking, and self-restraint in students.

Methods: The research method is descriptive and correlational. For this purpose, 384 students were selected from students at Bu-Ali Sina University through a multistage cluster sampling method in the (2017-2018) academic year. The research tools included the Ardelt wisdom scale (2003), Soltani philosophical mentality scale (1996), the social perspective-taking scale of Mohagheghi et al (2016) and Weinberger and Schwartz self-restraint scale (1990). Data were analyzed by Pearson correlation, multiple regression using SPSS software.

Results: The results revealed that philosophical mentality, social perspective-taking, and self-restraint could predict the wisdom with a beta coefficient of $0.35,0.21$, and 0.13 , respectively.

Conclusion: Based on the results of this research, it is suggested that with by emphasizing the importance and training of philosophical mentality, social perspective-taking, and self-restraint in the educational environments, it can enter wise people to the labor market and society.

Citation: Cheraghzadeh M, KordNoghabi R. Explaining of wisdom based on philosophical mind, social perspective-taking and self-restraint in student. Advances in Cognitive Sciences. 2020;22(2):1-11. 


\title{
تبين خرد بر اساس ذهنيت فلسفى، ديدكاهيرى اجتماعى و خودبازدارى در دانشجويان
}

\author{
مينا جراغزاده'، رسول كرد نوقابى"
}

ا ا. كارشناس ارشد روانشاسى تربيتى، دانشعاه بوعلى سينا، همدان، ايران

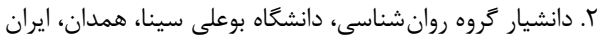

مقلدمه: خرد به عنوان بالاترين مرحله تحول شناختى و عالى ترين سطح تحول شخصيت فرد شناخته شده است. عوامل مختلفى از جمله، ذهنيت فلسفى به عنوان نوعى تفكر عميق در امور زندگى، ديدكاه گيرى اجتماعى به عنوان درك نقطه نظرات ديخران و همجنين خودبازدارى كه شامل كنترل شخصى در خصوص هيجانات بر خردورزى تأثيركذار هستند. هدف از يُوهش حاضر تببين خرد بر اساس ذهنيت فلسفى، ديدگاه گيرى اجتماعى و خودبازدارى در دانشجويان بود. روش كار: روش يزوهش حاضر توصيفى و از نوع همبستكى بود. بدين منظور رAr نفر از دانشجويان دانشعاه بوعلى سينا

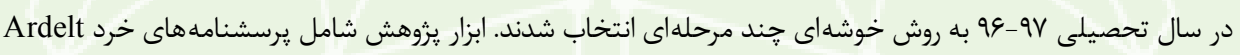

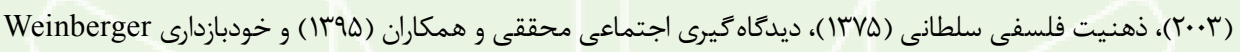
و Schwartz ( •199) بود. دادهها با استفاده از آزمون هاى همبستكى پييرسون، ركرسيون جندكانه به شيوه همزمان به وسيله از نرمافزار SPSS-22 تحليل شدند. يافته ها: نتايج يثرهش نشان داد ذهنيت فلسفى، ديدگاه گيرى اجتماعى و خودبازدارى به طور مثبت و معنادار به ترتيب با ضريب بتاى صس//، آ/ • و س// • قادر به بِيشبينى خرد مى باشند. نتيجه كَيرى: بر اساس نتايج اين يروهش يیشنهاد مى شود در محيطهاى آموزشى با تأكيد بر اهميت و آموزش ذهنيت فلسفى، ديدكاه
دريافت: 9.1.1\%

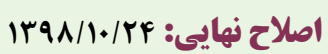

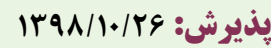
واثههاى كليدى

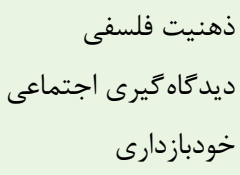

نويسنله مسئول رسول كرد نوقابى، ايران، همدان، دانشعاه بوعلى سينا، دانشكده اقتصاد و و علوم

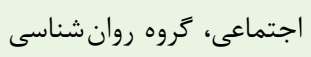

ايميل:Rkordnoghabi@gmail.com

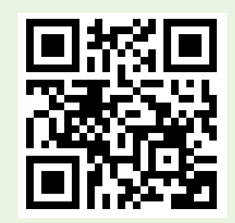

dol doi.org/10.30699/icss.22.2.1

مقدمبه

جند حافظه، مهارتهاى تحليلى و هوش اهميت بالايى دارند اما براى موفقيت در تحصيل و كار كفايت نمى كنند و اهميت مهارتهايى جون خرد مهمتر تلقى مىشود، لذا در طول قرنها در فرهنگ هاى مختلف خردمندى از والاترين فضائل قلمداد شده است ( (1). علاقه به بررسى خرد مقولهاى است كه در حوزههاى علمى مانند روانشناسى به سرعت رو به
رشد و تعالى انسان از مهممترين اهداف بشرى مىباشد، لذا شناسايى عوامل موثر براى رشد و شكوفايى همه جانبه شخصيت و استعدادهاى انسان همواره موضوع مهمى در اكثر جوامع بوده است، در اين راستا خرد (Wisdom) به عنوان آخرين سطح از رشد و تعالى انسانى نقش مهمى در رسيدن به اين هدف و يرورش انسانهاى شايسته دارد. هر 
توانايى بررسى انديشه هاى گوناگون را در خود بيابد (9). Ardelt

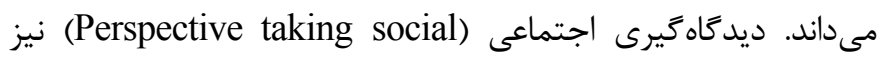

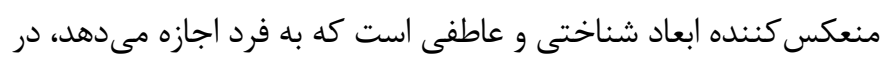

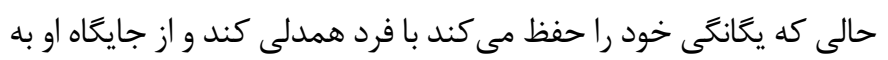

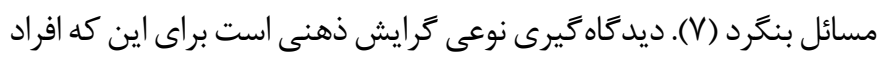

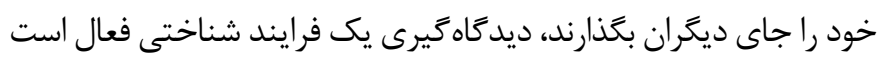

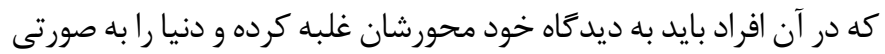
كه براى ديغران يديدار مىشود تصور نمايند. ديدگاه كيرى به طور صريح روى مؤلفه شناختى مربوط به حساسيت همدلانه تمركز دارد. از ميان

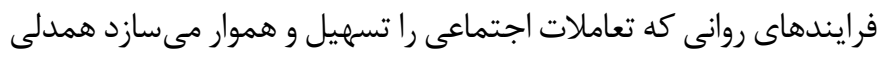
نقش كليدى را ايفا مى كند (^). از طريق ديدكاه گيرى اجتماعى افراد

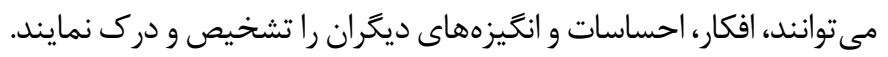

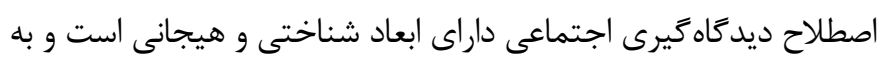

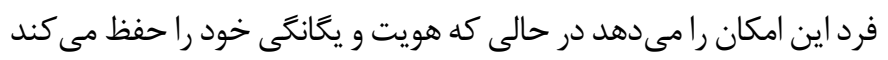

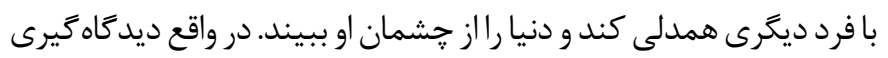

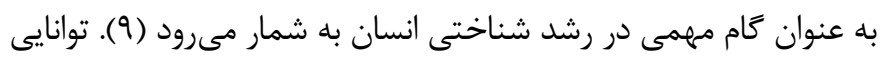
ديدكاه گيرى اجتماعى از لحاظ نظرى بار شد معرفت شناختى همر اه است و در رديف مهارتهاى سطح بالاى شناختى، نظير تفكر انتقادى، حل مسئله

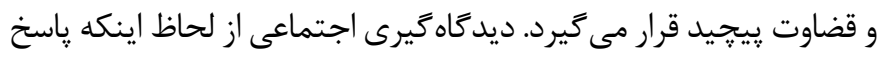

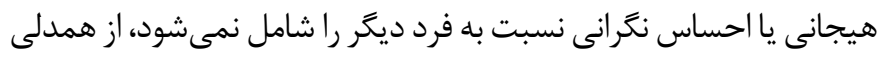

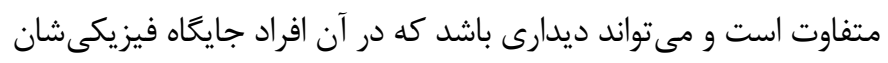

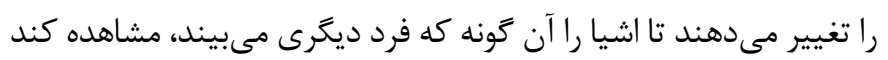

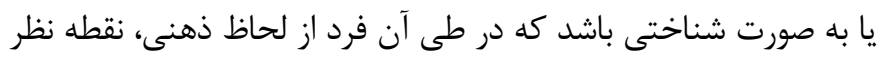

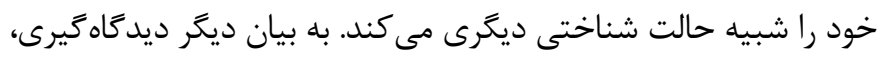
فر آيند تعليق نقطه نظر شخصى يك فرد در تلاش براى ديدن يك موقعيت

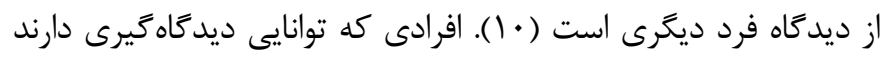
ممكن است ديدكاه مثبت ترى داشته باشند و مىتوانند نيازها، علايق و

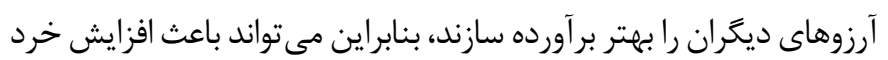

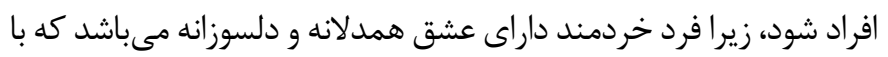

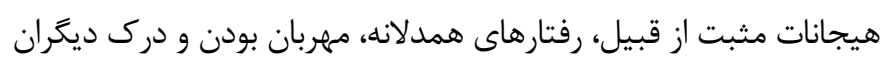
همراه است (11). هر קند ذهنيت فلسفى و ديدگاه گيرى اجتماعى ممكن است به عنوان

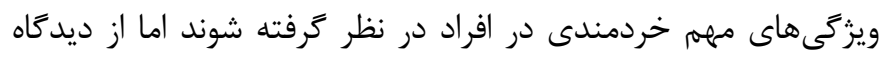
Ardelt

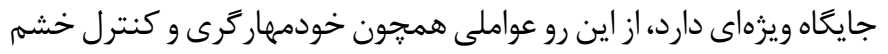
نيز با خرد مىتوانند در ارتباط باشند. خودبازدارى (Self-restraint) به
فزونى مىباشد كه در طول دو دهه كذشته، يزوهشهاى روانشناسى

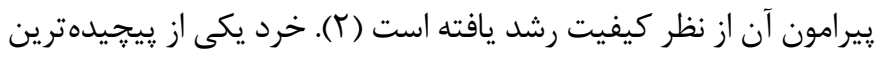

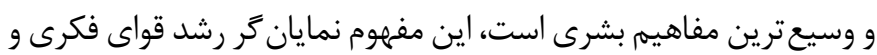

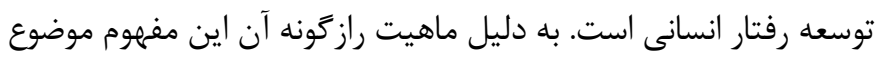

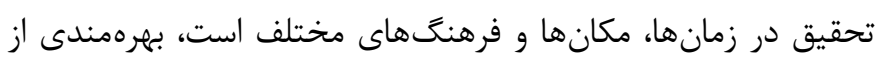

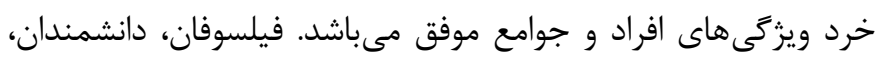

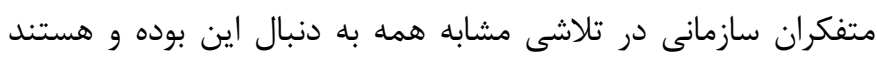

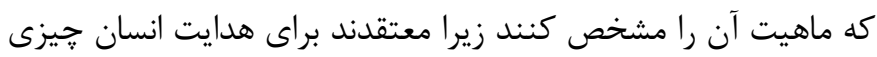

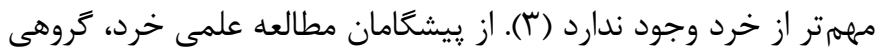
تحت عنوان خرد Berlin هستند كه خرد را نوعى تخصص در مسائل بنيادين زندكى تعريف كردهاند. خرد برخوردارى از بينش عميق و قضاوت

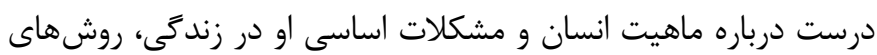

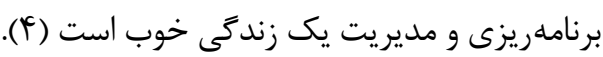
Ardelt

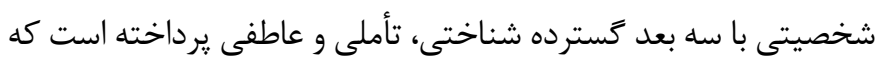

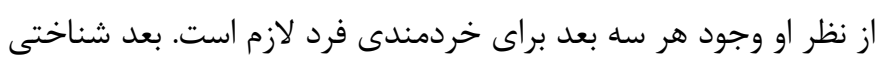
خرد نشاندهنده ميل به دانستن حقيقت و درك عميق از زندكى است.

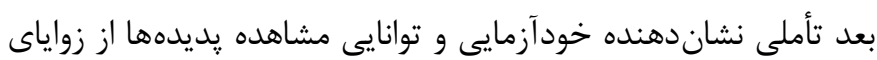

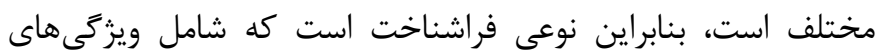
درون نكر انه و شهودى است و بعد عاطفى به عنوان عشق همدلانه، مهربان

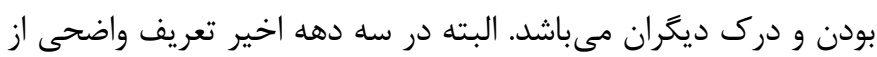

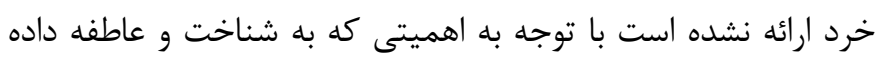

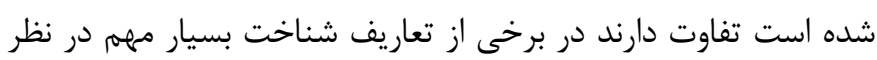

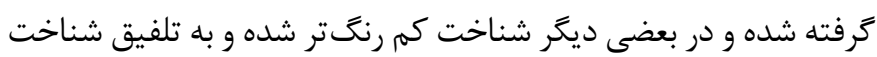

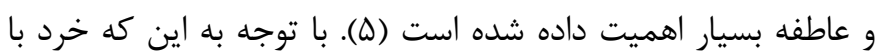
دانش، آكاهى و شناخت همراه است و از سويى افزايش دانش، توانيى الهيى تفكر انتزاعى، توانايى تفكر در مورد جنبههاى متعدد يك موقعيت به طور همزمان از ويزَّى هاى ذهنيت فلسفى (Philosophical mind) به شمار مىروند، به نظر مىرسد خرد با ذهنيت فلسفى در ارتباط باشد. ذهنيت فلسفى معادل روح فلسفى خصوصياتى است كه در رفتار و طرز

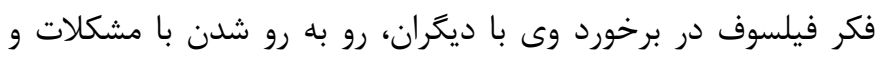

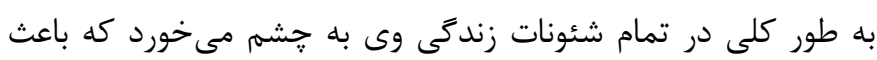

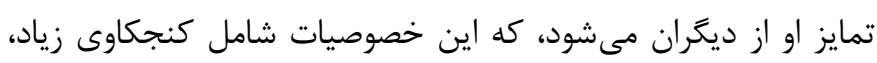

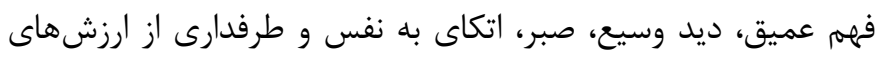

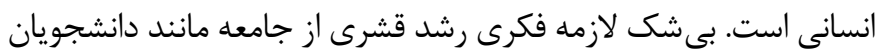

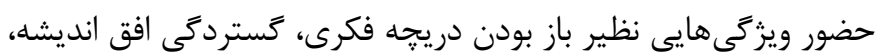
كشودگى فضاى انديشه و انعطاف يذيرى است تا بر مبناى اين خصوصيات 
داردند، ذهنيت فلسفى به عنوان نوعى تفكر عميق در امور زندگى و حقايق،

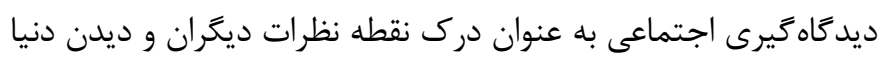

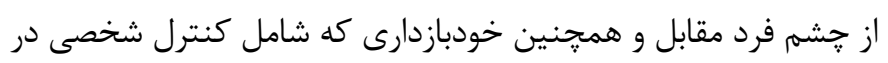

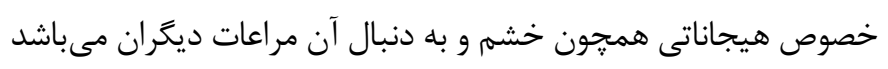

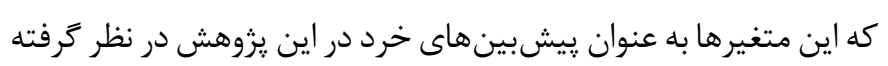

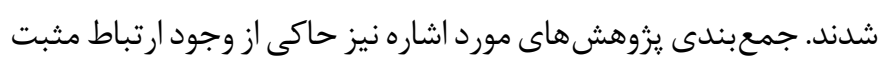

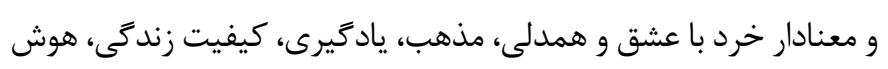

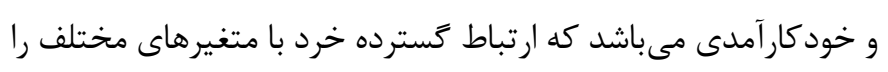

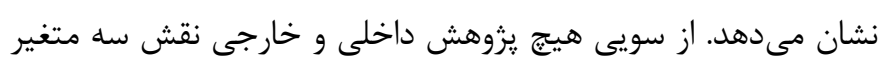

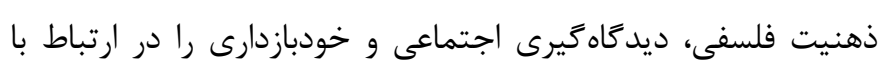

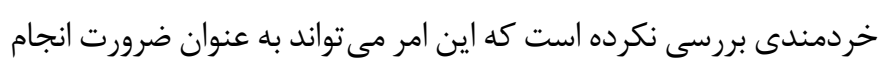

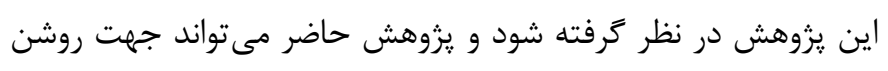

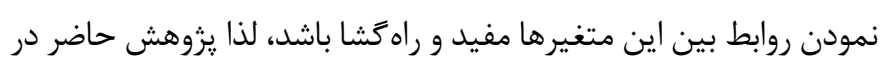

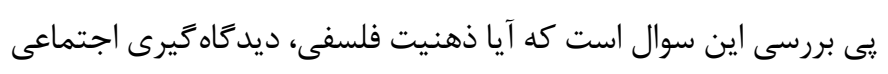

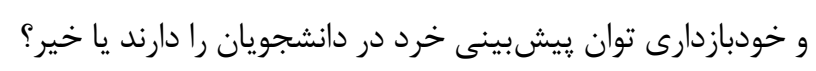

\section{روش كار}

با توجه به اين كه هدف يزوهش حاضر، تبيين خرد بر اساس ذهنيت

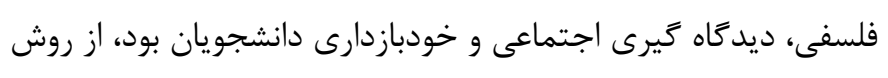

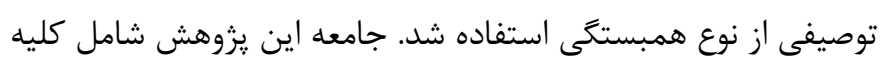
دانشجويان مقطع كارشناسى و كارشناسى ارشد دانشعاه بوعلى سينا

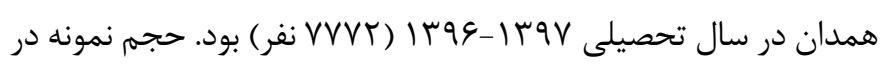

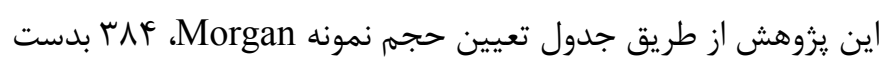

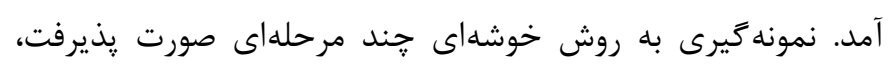

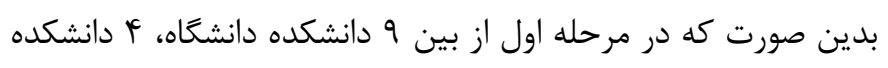
(فنى و مهندسى، كشاورزى، علوم يايه و اقتصاد و علوم اجتماعى)،

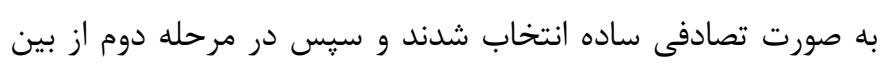

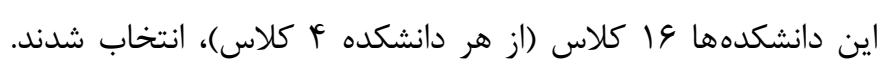

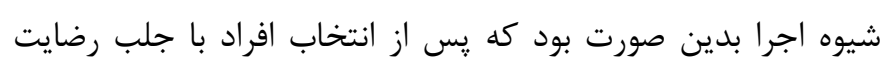

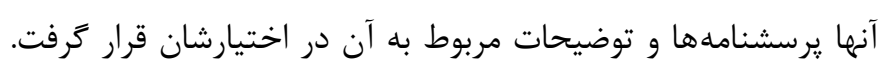

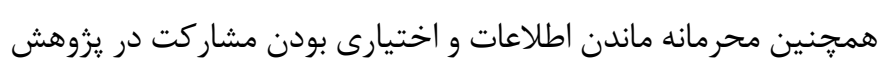

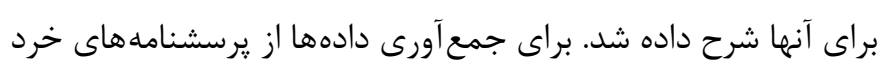
Ardelt

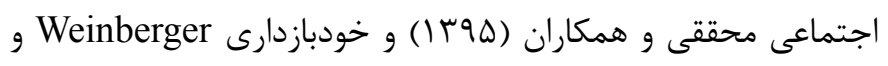
(199. ) Schwartz مقياس سه بعدى خرد (Three Dimensional Wisdom Scale):

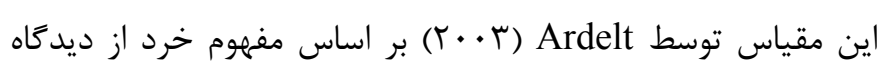

معناى سركوب تمايلات خودخواهانه است و در واقع توانايى و كرايش به سر و سامان دادن احساسها، رفتارهاى كلامى و غير كلامى و ديكر

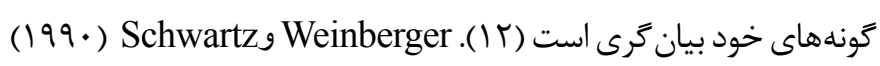

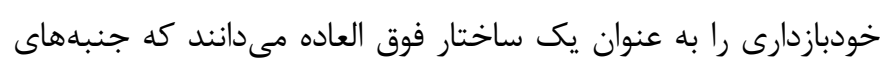

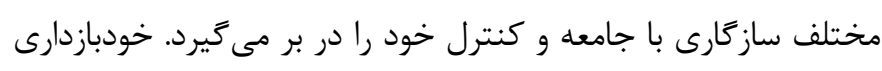

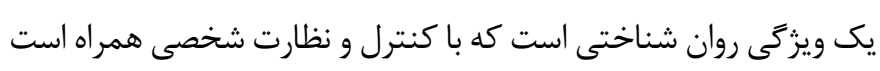

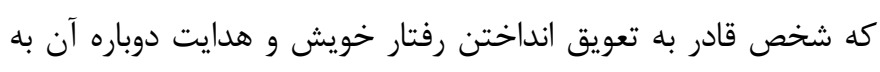

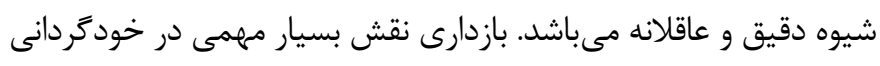

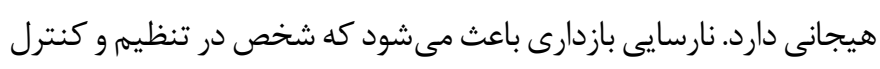

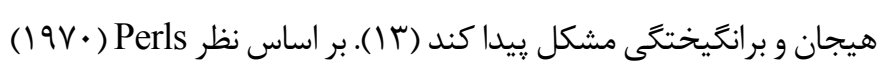
اشخاص سالم مى توانند مسئوليت زندگى خودشان را بيذيرند، مئى دانند كه

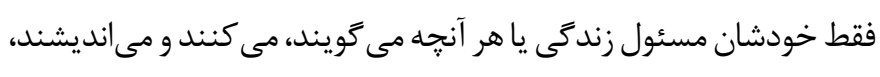
هستند و نيز مى كويد هر اركانيسمى براى حفظ تعادل، همواره به تعادل

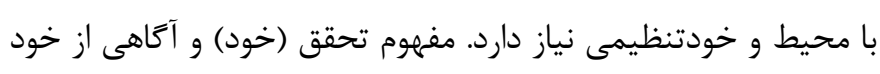

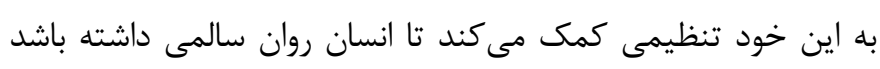

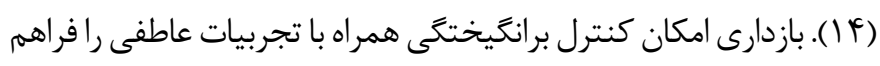

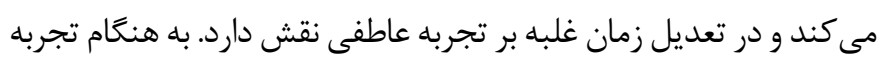
حالتهاى عاطفى اخر محرى عاطفى توانايى بازدارى را سلب كند، اعمال بازدارى عاطفى مختل مى شود و تنظيم موثر حالت هيجانى رخ نمى دهدي. يك رويكرد در تبيين اين بد تنظيمى هيجانى، به سوخيرى توجه ناشى از وناز

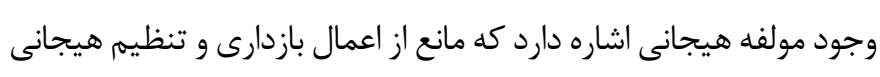

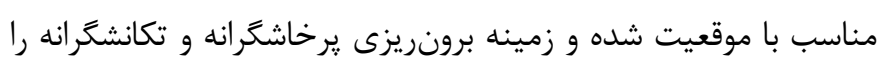
فراهم مى آورد (ه) (1). در زمينه ارتباط همه متغيرهاى يزوهش حاضر مارد مطالعهاى صورت نكرفته

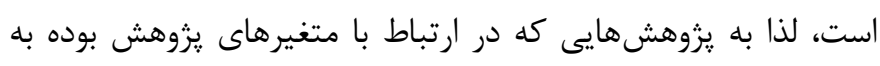

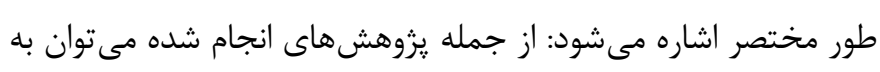

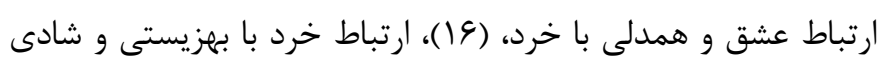

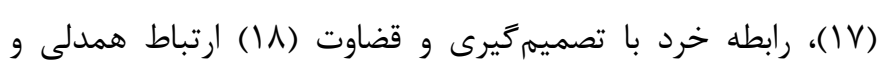

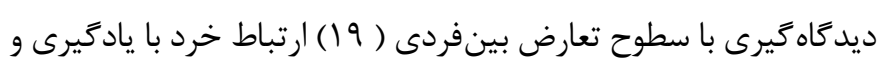

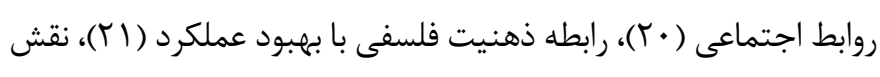

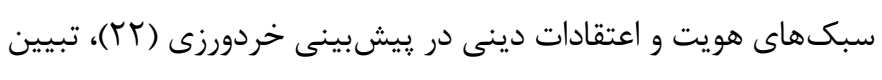

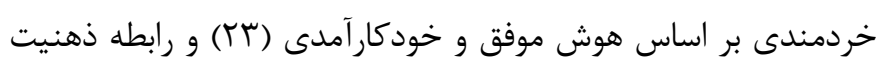
فلسفى با هوش معنوى (TY)، اشاره كرد.

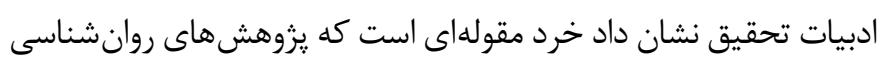

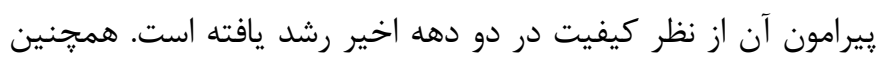

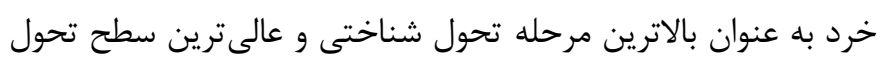

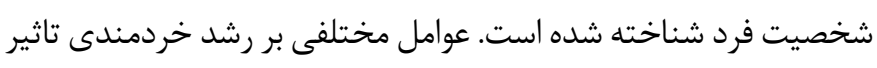


واكنشيذيرى بينفردى Davies (•191) و سا گويه از مقياس بهره

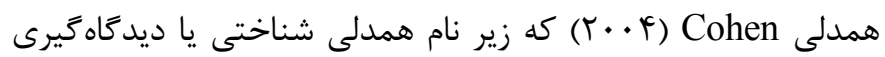

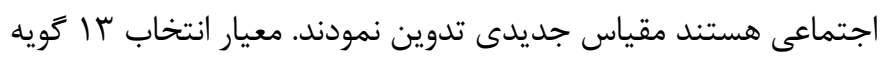

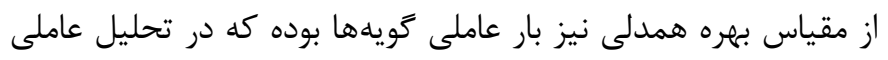

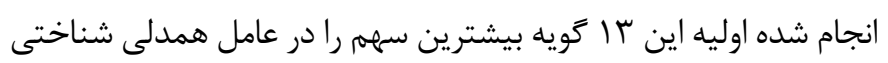

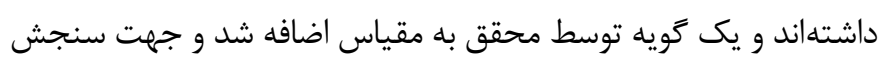

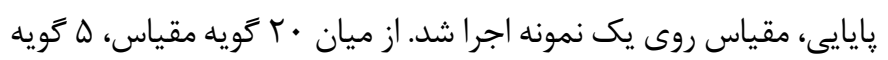

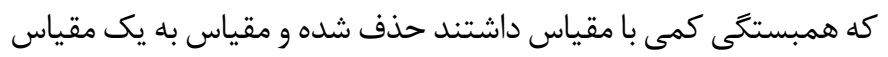

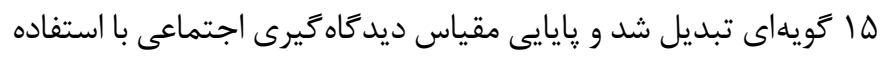

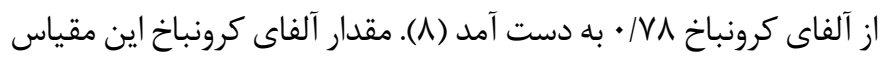

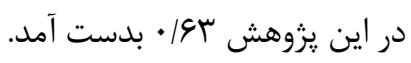

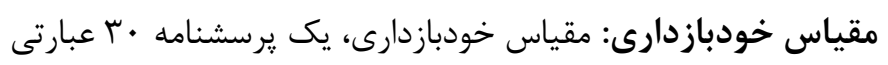

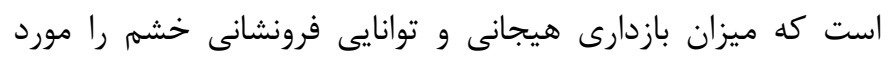

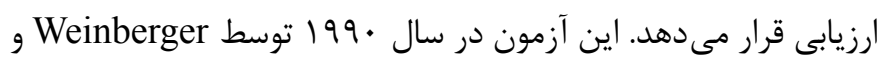

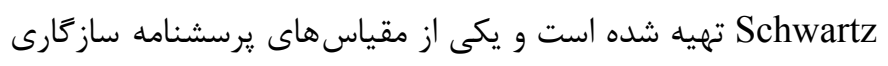
Weinberger يك مقياس كلى و † ز زير مقياس است. زير مقياس مهاى اين آزمون

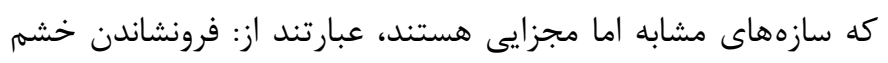

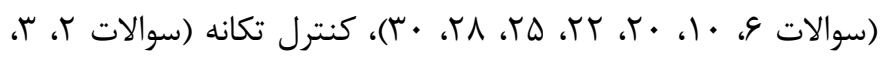

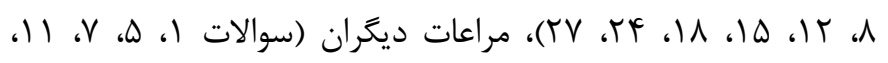

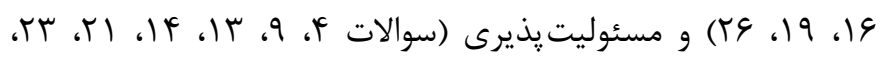

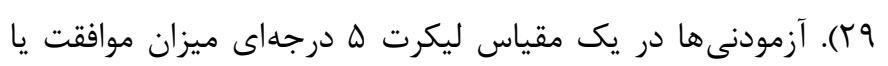

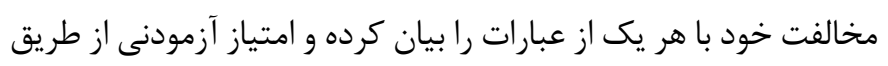

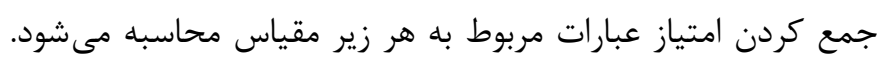
(1991) Weinberger

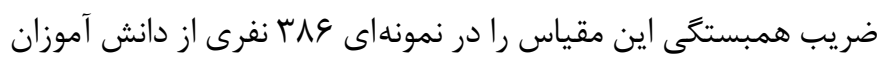

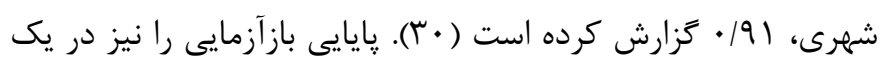

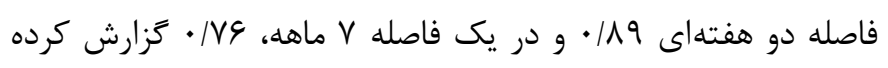
است. Weinberger و و (1994)، همسانى درونى كل آزمون

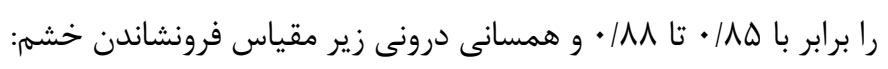

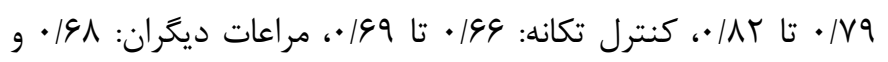

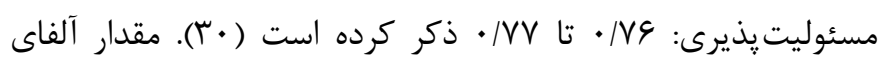

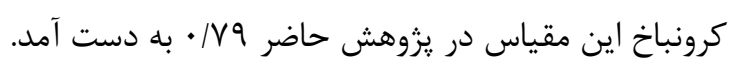

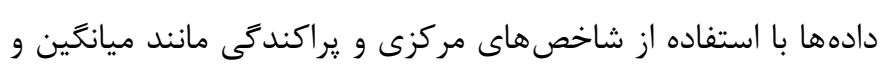

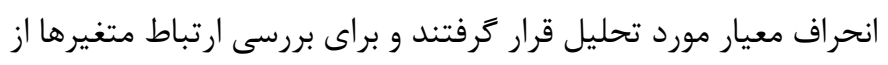

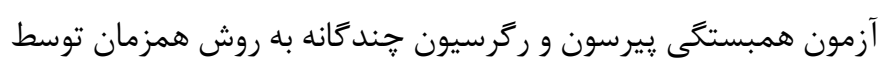

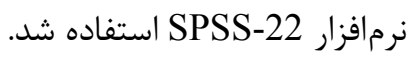

Birren و Clayton به عنوان متغيرى مكنون با شاخصهاى اثرشناختى، عاطفى، و تأملى

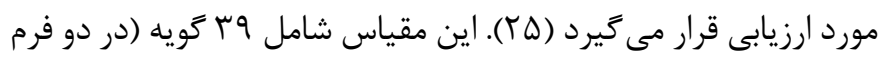

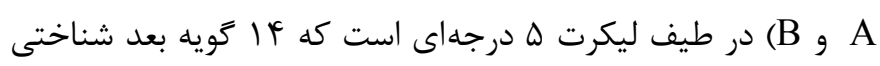

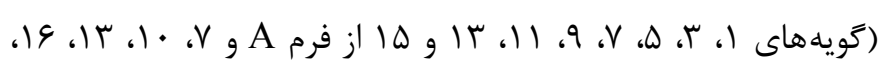

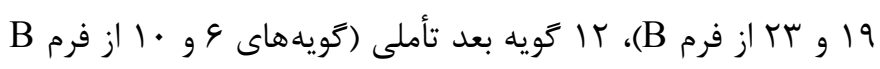

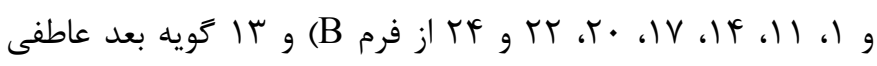

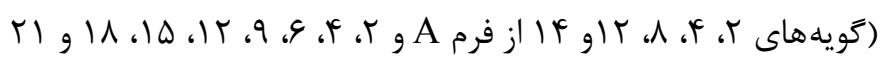

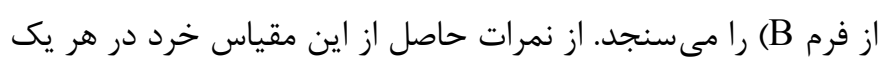

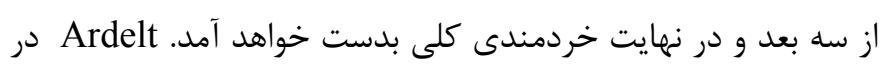

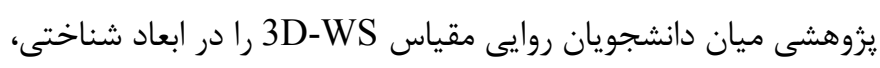

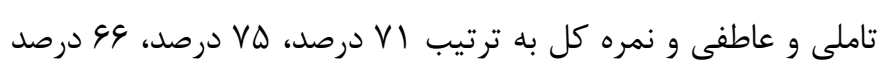

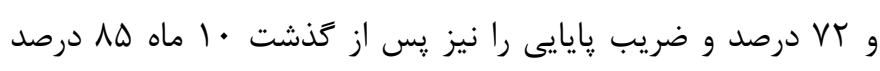

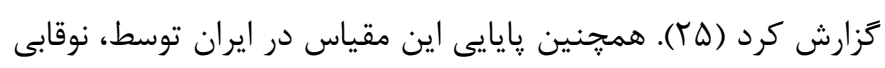

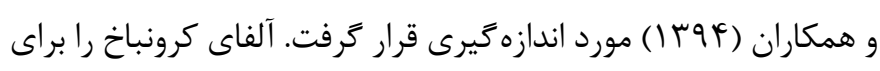

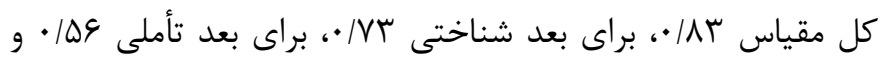

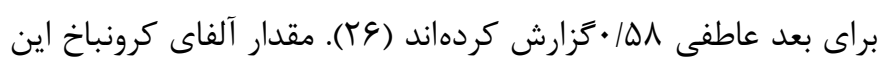

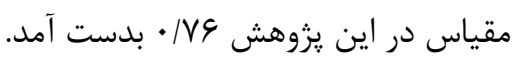

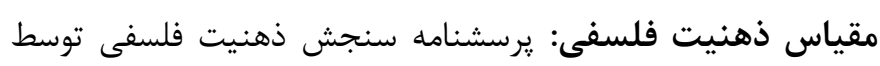

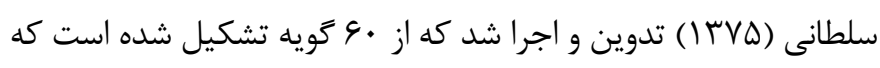
به منظور سنجش ميزان ذهنيت فلسفى افراد به كار مىرود. نمره كذارى

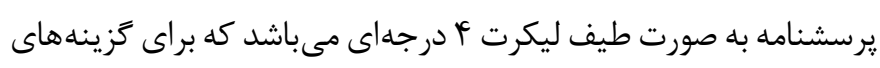

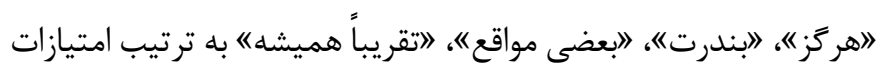

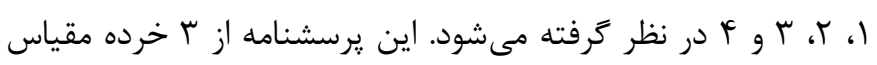

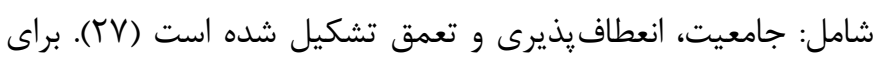
سنجش روايى يرسشنامه ذهن فلسفى، از روش اعتبار سازه استفاده شده

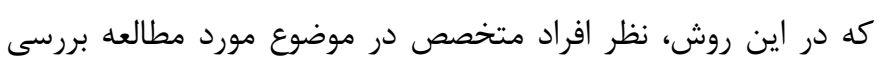

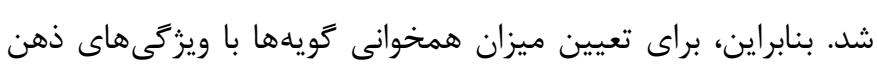

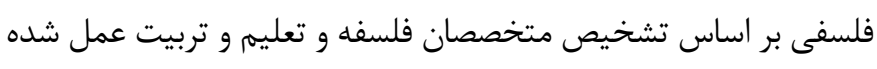

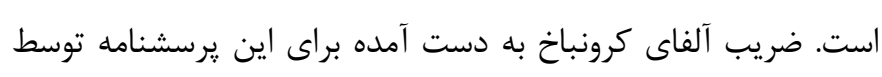

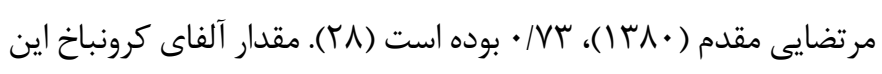

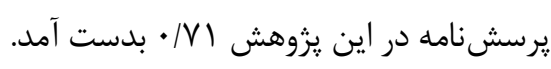
مقياس ديدكاه

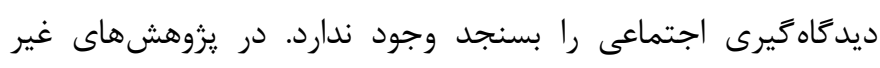

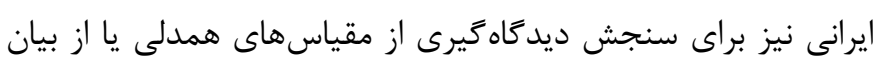

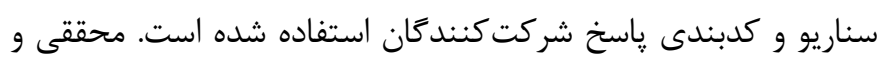

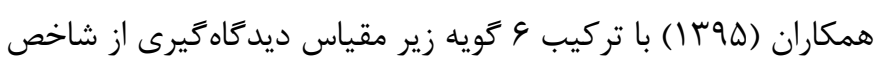


بافته ها

و انحراف استاندارد نمرات در مقياسهاى خرد، ديدگاهگيرى اجتماعى، ذهنيت فلسفى و خودبازدارى در جدول r ارائه شده است. همان گونه كه

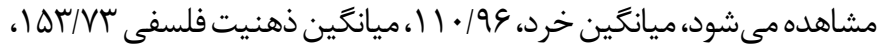

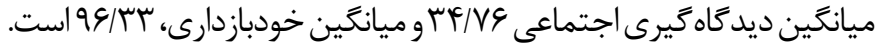

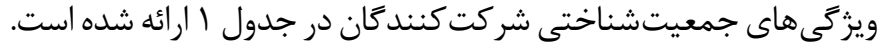
براى بررسى سوال يزوهش، از ركرسيون جندگَانه استفاده شد. در مدل رگرسيون، متغيرهاى خودبازدارى، ذهنيت فلسفى و ديدگاهَيرى اجتماعى به عنوان ييشبين و خرد به عنوان متغير ملاك در نظر گرفته شدند. ميانگين

جدول 1. ويزگى جمعيتشناختى شركت كنندكان در يزوهش

\begin{tabular}{|c|c|c|c|}
\hline درصد & تعداد & جنس & مقطع \\
\hline$r q / r$ & 101 & 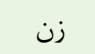 & \multirow{3}{*}{ كارشناسى } \\
\hline$r T / \Lambda$ & ITS & مرد & \\
\hline$V T / I$ & TVV & كل & \\
\hline $\mid f / 9$ & $\Delta \varphi$ & زن & \multirow{3}{*}{ كارشناسى ارشد } \\
\hline r & $\Delta 1$ & مرد & \\
\hline$r V / q$ & $1 \cdot V$ & كل & \\
\hline
\end{tabular}

جدول r. شاخص هاى گرايش مركزى و نتايج آزمون كلموكروف_اسميرنف براى متغيرهاى مورد مطالعه

\begin{tabular}{|c|c|c|c|c|c|}
\hline $\mathbf{P}$ & $\mathbf{Z}$ & خطاى معيار & ميانگين & فراوانى & متغيرها \\
\hline$\cdot / r \cdot$ & .1 .90 & .199 & $11 \cdot 199$ & rAf & خرد \\
\hline$\cdot / r \ldots$ & $\cdot|| \Delta \mid$ & $\cdot|\Lambda|$ & IQT/VT & rAF & ذهنيت فلسفى \\
\hline$\cdot / \pi \cdot$ & . IIrF & r & TH/VG & rar & ديدَاه حيرى اجتماعى \\
\hline $.1 \cdot 94$ & $\cdot / 4 / \Lambda$ & $\cdot \mid \Delta F$ & سצ/ & ruf & خودبازدارى \\
\hline
\end{tabular}

واريانس استفاده شد كه نتايج آن در جدول ب ارائه شده است. بر اساس اطلاعات جدول "ا، همان گونه كه مشاهده مى شود، مقدار

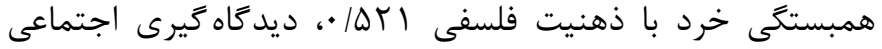

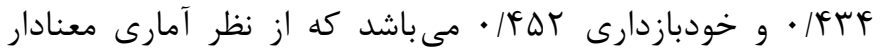
است ( ( • P P). نتايج شاخص ضريب تحمل براى متغيرها بالاتر از ץ/ • است و در محدوده مناسبى است، همجنين شاخص تورم واريانس نيز زير ب بدست آمده كه در محدوده مناسبى است. در ادامه تحليل رگرسيون جند زانه اجرا شد كه نتايج آن در جداول أز و له ارائه شده است.
براى اجراى رگرسيون קيشفرض هاى نرمال بودن با آزمون كلموگروفــ اسميرنف مورد بررسى قرار گرفت و مقدار معنادارى براى همه متغيرها بيشتر از ه • • بود و فرض نرمال بودن مورد يذيرش قرار گرفت (جدول r). براى بررسى رابطه خطى بين متغيرها از همبستخى ييرسون استفاده شد كه نتايج حاكى از ارتباط معنادار بين متغيرها داشت همه روابط در

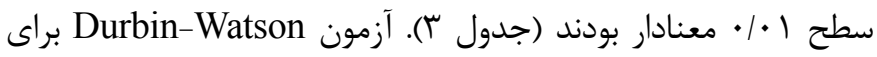
ارزيابى استقلال خطاها به كار رفت كه ميزان اين آماره \&V/ بدست آمد

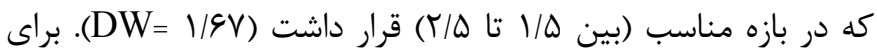
بررسى همخطى بين متغيرها از شاخصهاى ضريب تحمل و عامل تورم 
جدول r. آزمون همبستكى بيرسون جهت بررسى خطى بودن رابطه بين متغيرها

\begin{tabular}{|c|c|c|c|c|c|c|}
\hline تورم واريانس (VIF) & آماره تحمل & p & r & $r$ & 1 & متغير \\
\hline $1 / \cdot 1$ & .191 & & & & - & ا. ذهنيت فلسفى \\
\hline $1 / \pi 4$ & $\cdot / V r$ & & & - & 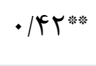 & r. ديدگاه گيرى \\
\hline 1/א & $\cdot / V r$ & & - & $\cdot \mid \varphi^{*}$ & . & س. خودبازدارى \\
\hline- & - & - & $\cdot / \mathbb{A} \Delta^{\text {*⿻*s }}$ & 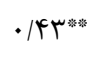 & 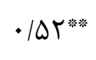 & F أ خرد \\
\hline
\end{tabular}

** $\mathrm{P}<\bullet / \cdot 1$

براى ييشبينى خرد بر اساس ذهنيت فلسفى، ديدگاهگيرى اجتماعى و خودبازدارى، از لحاظ آمارى معنادار است. با توجه به مجذور R، متغيرهاى ييشبين در معادله ركرسيون مى توانند تاعبا درصدواريانس خرد راتبيين كنند.

جدول †ٔ، آزمون تحليل واريانس را جهت بررسى معنادارى مدل رگرسيون

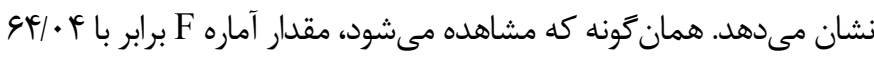
بوده و از لحاظ آمارى معنادار مىباشد (1 • P<). بنابراين، مدل رگرسيون

جدول ₹ا. نتايج تحليل ركرسيون خندكانه براى بيش بينى خرد توسط ذهنيت فلسفى، ديدكاه گيرى اجتماعى و خودبازدارى

\begin{tabular}{|c|c|c|c|c|c|c|c|}
\hline $\mathbf{R}^{2}$ & $\mathbf{R}$ & $\mathbf{P}$ & $\mathbf{F}$ & ميانگين مجذورات & درجادي & مجذموع & مدل \\
\hline \multirow{3}{*}{$\cdot / \mu F$} & \multirow{3}{*}{$\cdot|\Delta|$} & \multirow{3}{*}{$\cdot 1 \cdot \cdot 1$} & \multirow{3}{*}{$s q / \cdot F$} & $V \backslash \Delta N / Y \backslash$ & r & TIFVF/GT & ركرسيون \\
\hline & & & & $111 / \mathrm{r}$ & ґی. & FYFYF/VI & باقى مانده \\
\hline & & & & & rیr & qrq४q/rr & كل \\
\hline
\end{tabular}

به مقادير ضرايب رگرسيون استاندارد، ذهنيت فلسفى با مقدار آماره بتاى

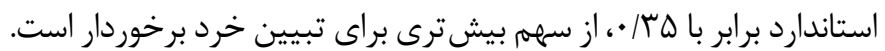

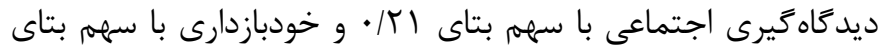
س / • در تبيين خرد نقش معنادارى دارند.
جدول ه، ضرايب رگرسيون را براى تبيين سهم هر يك از ذهنيت

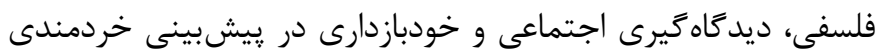
نشان مى دهد. همان گونه كه مشاهده مىشود، همه ضرايب مربوط بـ به اين عامل ها، از لحاظ آمارى معنادار است ( • P> P). همجنين، با توجه

جدول ه. ضرايب استاندارد شده مدل ييشبينى خرد بر اساس ذهنيت فلسفى، ديدَاه كيرى اجتماعى و خودبازدارى

\begin{tabular}{|c|c|c|c|c|c|}
\hline \multirow[t]{2}{*}{$\mathbf{P}$} & \multirow[t]{2}{*}{$\mathbf{t}$} & \multirow{2}{*}{ ضرايب رَرسيون } & \multicolumn{2}{|c|}{ ضرايب رَرسيون غير } & \multirow[t]{2}{*}{ متغير } \\
\hline & & & خطاى معيار & B & \\
\hline$\cdot|\cdot|$ & Q/IT & --- & ه/^৭ & $r \cdot / r r$ & ثابت \\
\hline$\cdot 1 \cdot \cdot 1$ & $9 / 09$ & $\cdot / \pi \Delta$ & $\cdot / \cdot r$ & $\cdot / r \Lambda$ & ذهنيت فلسفى \\
\hline$\cdot 1 \cdot .1$ & F/Ar & $\cdot|r|$ & $\cdot / 1 F$ & .194 & ديدكَاه حَيرى اجتماعى \\
\hline$|\cdot r|$ & $r / \mu)$ & r & $\cdot / \cdot V$ & .119 & ثابت \\
\hline
\end{tabular}


اجتماعى ايفا مى كند، مى توان ارتباط آن را با خرد منطقى در نظر كرفت.

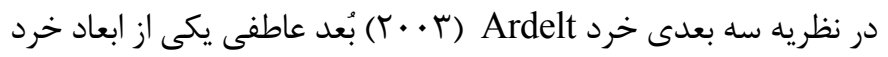

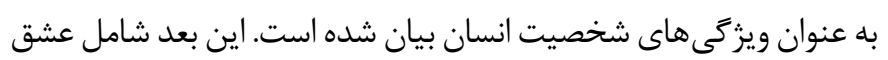

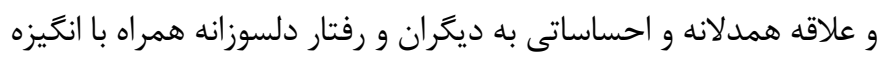

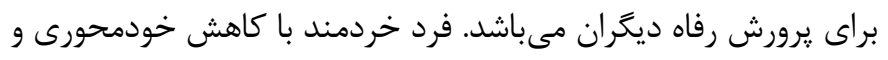
بينش عميق نسبت به رفتار خود قادر به همدلى و عشقورزى بـ به ديه ديكران

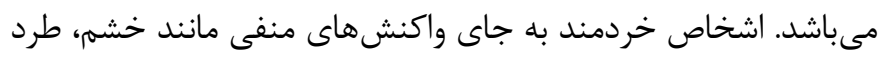

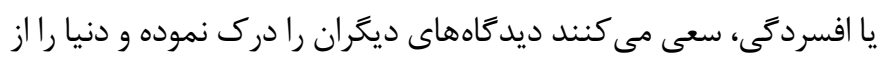

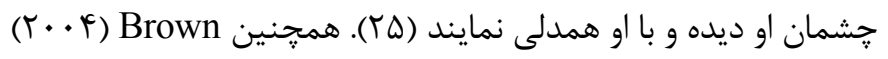

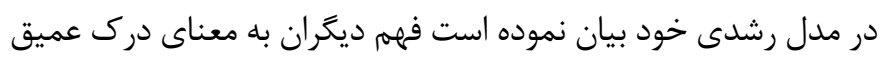

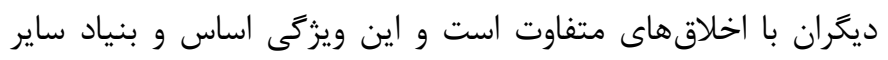

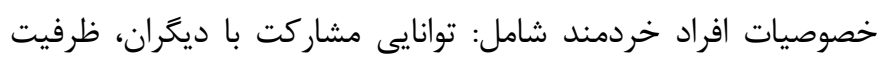

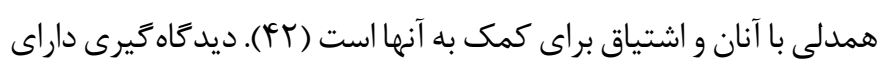

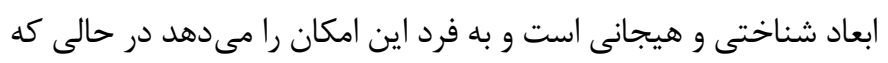

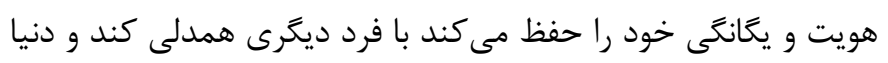

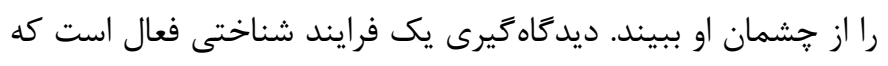

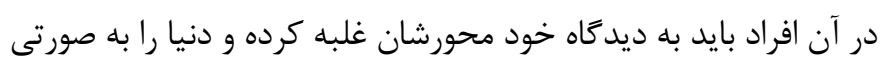

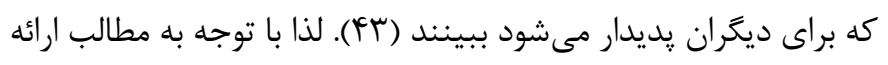

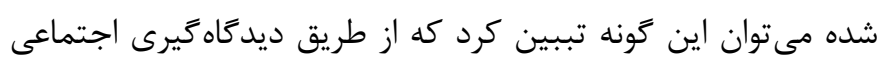

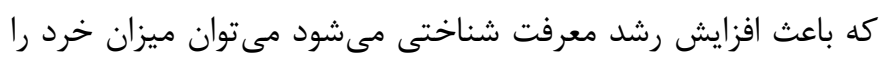
افزايش داد. همجنين ديدگاه

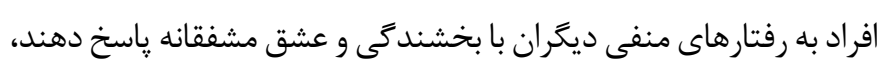

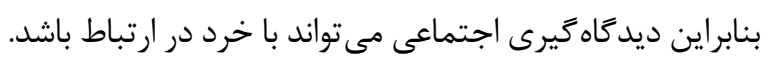

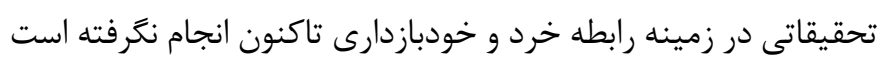

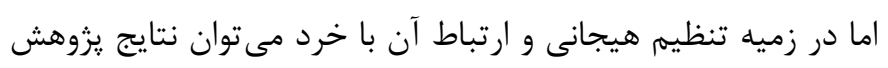

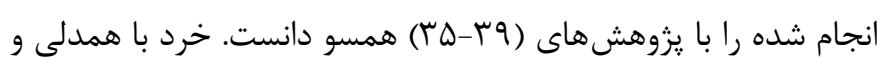

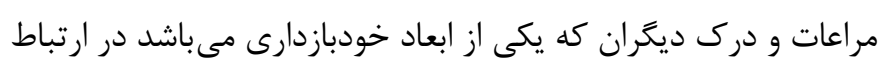

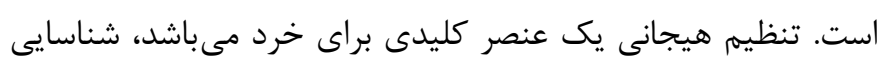

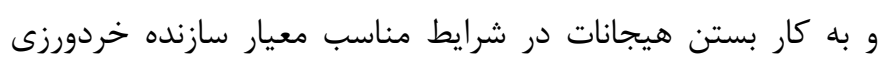

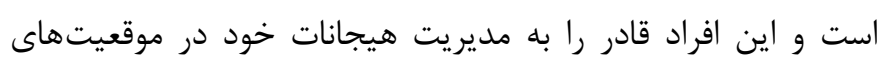

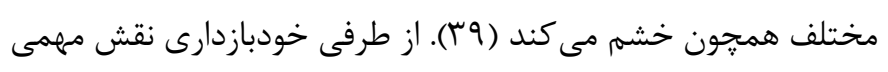

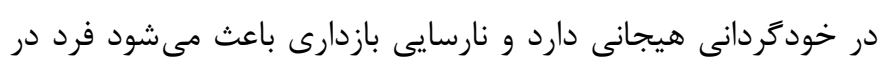

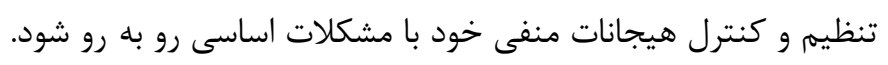

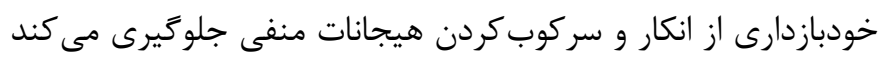

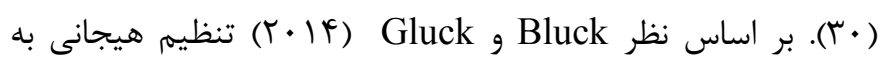

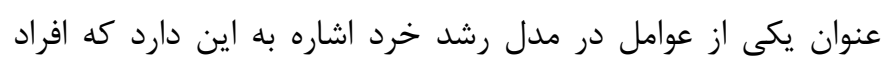

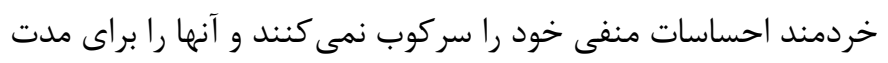

هدف يزوهش حاضر تبيين خرد بر اساس متغيرهاى ذهنيت فلسفى،

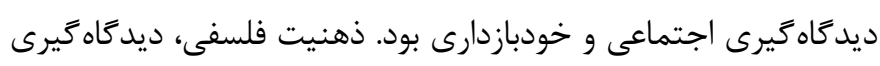

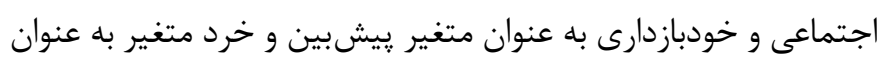

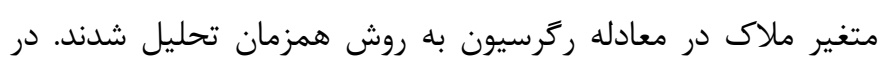

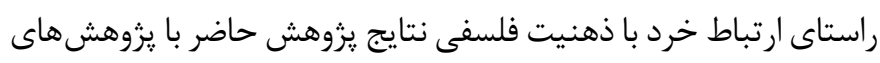

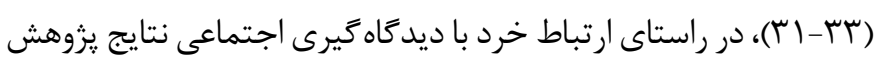

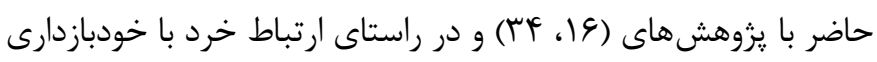

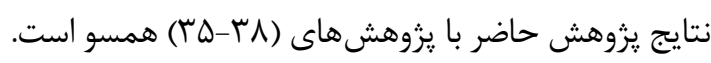

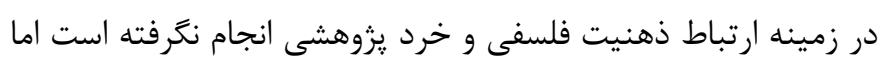

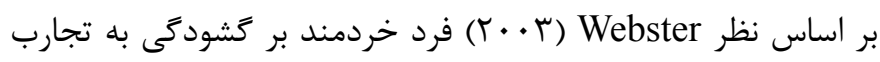

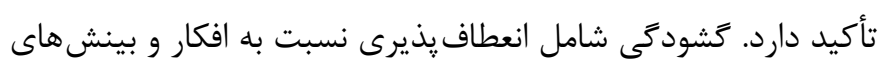

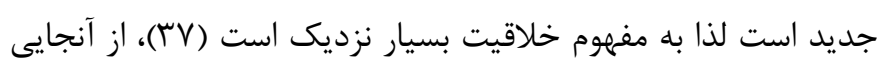

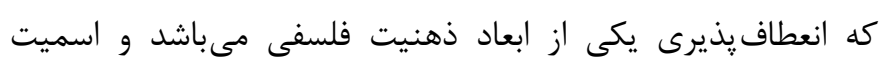

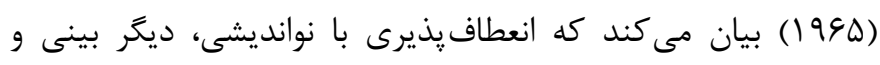

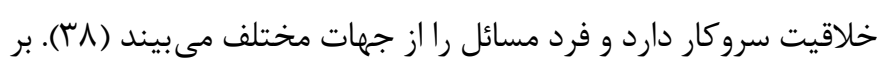

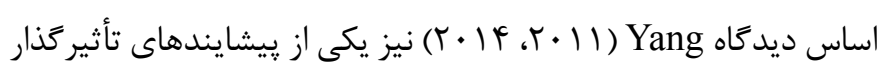

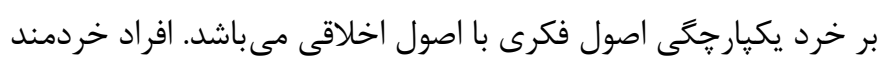

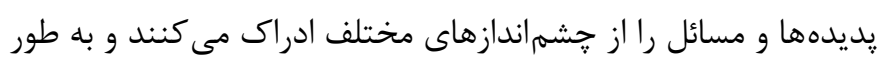

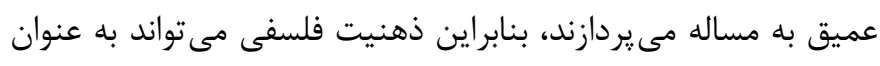

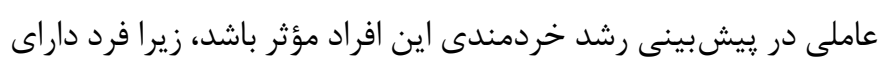

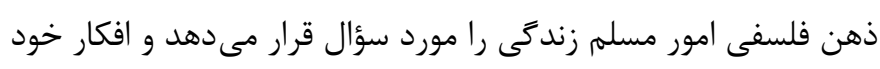

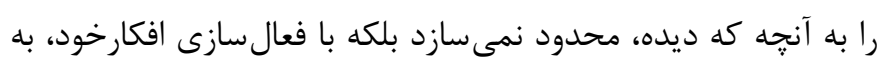

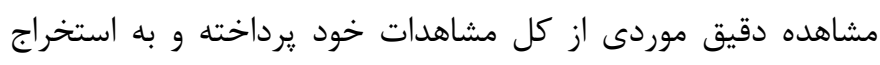

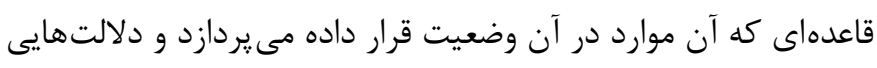

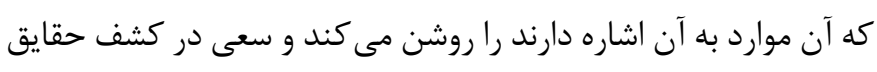

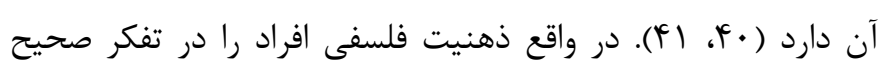

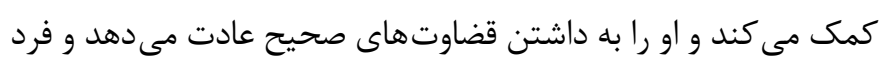

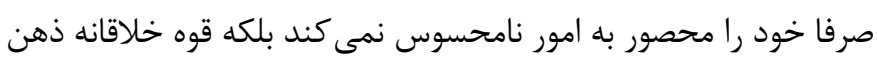

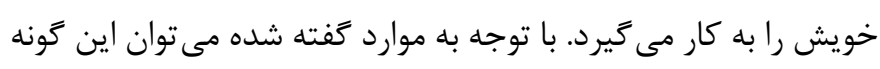
تببين كرد كه ذهنيت فلسفى با خرد رابطه مثبت و معنادارى دارد و

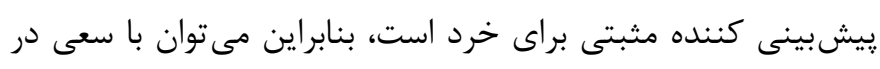

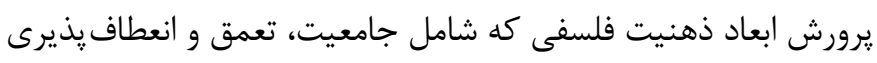
است ميزان خرد راد در دانشجويان افزايش داد.

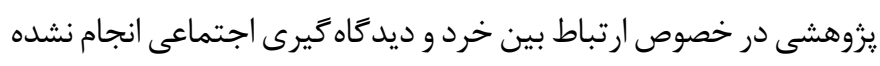

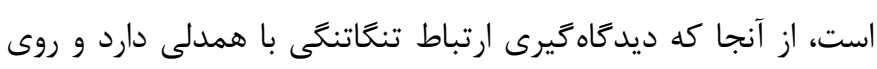

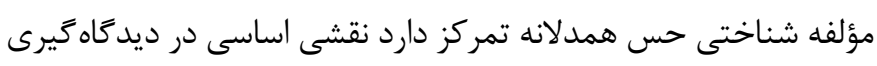


مى توانند ديدكاهها و هيجانات فرد ديخر را درك كنند و ديدگاه گيرى

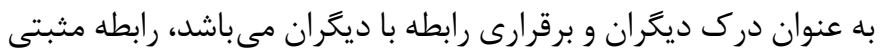
داشته باشد. با توجه به اهميت خرد به عنوان يكى از سازههاى مهمى

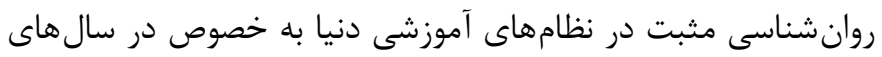
اخير، شناسايى بيشايندها و متغيرهاى مرتبط با خردمندى بيام هاى

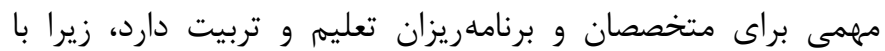

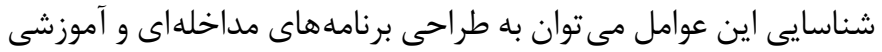
در زمينه افزايش خردمندى دانشجويان يرداخت. زيرا نبايد همجون كذشته تنها بر هوش و مهارتهاى تفكر تأكيد كرد و آنها را دغدغه رئه نظامهاى آموزشى دانست، بلكه با فراهم آوردن محيطهاى آموزشى تهى تهري غنى مى توان افراد خردمند را وارد جامعه ساخت.

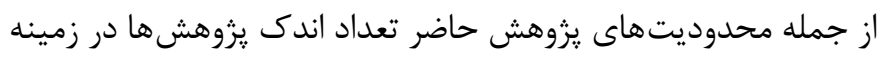

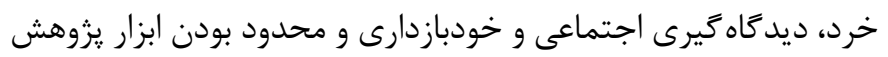

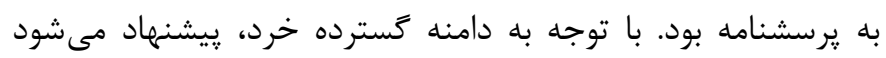
متغيرهايى مانند حل مسأله، نقش معنا در زندگى و تنظيم هيجانى با بانها خرد در يزوهش هاى آتى مورد بررسى قرار گيرند.

\section{نتيجه كَيرى} اين يزوهش با هدف تببين خرد بر اساس ذهنيت فلسفى، ديدگاهگيرى اجتماعى و خودبازدارى انجام شد. نتايج نشان داد ذهنيت فلسفى، بادي،

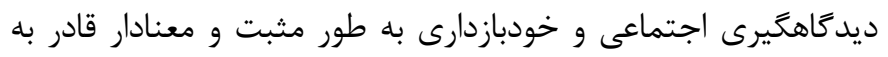

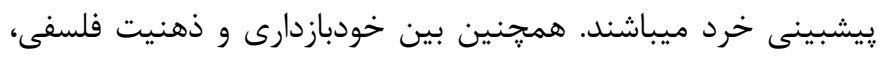
بين ذهنيت فلسفى و ديدَاهًَيرى اجتماعى و بين خودبازدارى و ديدَاهكيرى اجتماعى همبستگى مثبت و معنادارى وجود دارد كه وجود اين ارتباطها تأكيد بر اهميت و آموزش ذهنيت فلسفى، ديدكاهگيرى اجتماعى و خودبازدارى به منظور بالابردن خرد افراد را نشان مىدهد.

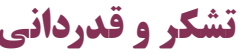

اين مقاله حاصل پاياننامه كارشناسى ارشد روانشناسى تربيتى است.
زيادى درون خود نخه نمى دارند، اما آنها بايد هيجانات منفىشان را محدود كنند و كنترل و بازدارى بيشترى روى هيجاناتشان داشته باشند، بنابراين بين خرد و خودبازدارى رابطه مثبت و معنادارى وجود دارد (qץ). همجنين خرد كه شامل رفتارهاى دلسوزانه و نداشتن هيجانات منفى نسبت به ديخران و همجنين فهمم و درك افراد مىباشد، با مراعات ديخران به عنوان يكى از ابعاد خودبازدارى به معناى فهمه و درى احساس و هيجات ديخرى و يا برقرارى ارتباط عاطفى با شخص بـ ديكر است رابطه مثبت و معنادارى دارد. بنابراين با توجه به مطالب كَفته شده مىتوان اين كونه تبيين كرد كه خودبازدارى با جلوكيرى از

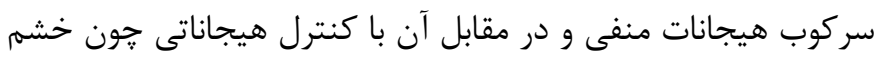

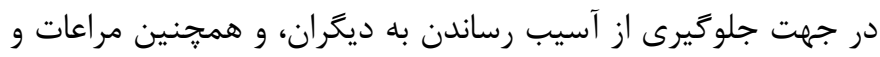

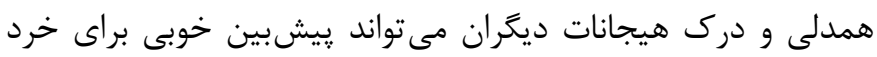

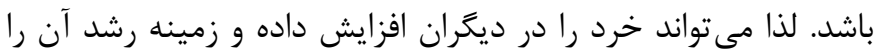

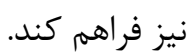

ذهنيت فلسفى با تأكيد بر انعطافيذيرى، نوانديشى و مشاهده دقيق حقايق و توانايى صحيح در قضاوت كردن موجب رشد توانايى خرد مىشود. همجنين ديدگاه گيرى اجتماعى با تأكيد بر همدلى، عاطفه، درك ديخران و رشد معرفت شناختى بيشبينى كننده موثرى براى خرد مى باشند. خودبازدارى با مديريت هيجان در شرايط مختلف و بازدارى و كنترل روى هيجانات به خصوص كنترل خشم و تكانه و

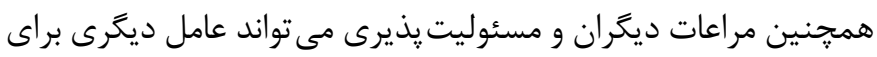

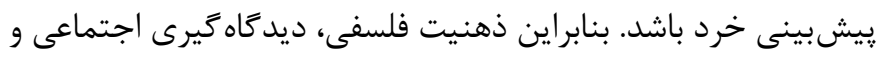
خود بازدارى سه عنصر موثر در خصوص يیشبين بينى ميزان خرد در افراد به ويزه دانشجويان نقش مهمى دارند. از آنجايى كه خرد مولفههايى مانند رسيدن به درك عميق زندكى، درك و همدلى نسبت به ديخران و توانايى مديريت هيجانات را در بر مى گيرد مى تواند با متغيرهايى مانند ذهنيت فلسفى كه باعث مى شود افراد به مسائل كوناكون نكاه عميقترى داشته باشند، خودبازدارى كه

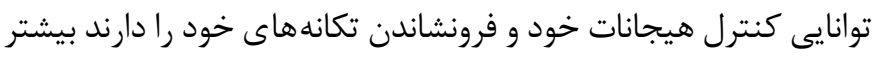

\section{References}

1. Walsh R, Reams J. Studies of Wisdom: A special issue of integral review. Integral Review. 2015;11(2):1-6.

2. Staudinger UM, Gluck J. Psychological wisdom research: Commonalities and differences in a growing field. Annual Review of Psychology. 2011;62:215-241.

3. Po Keung IP. Kingly governance as wise management. International Conference on Wise Management in Organizational Complex. 2011 May 23-24; Shanghai, China;2011.

4. Kord Noghabi R. Psychology of wisdom, Tehran:Arjmand Publication;2016. (Persian) 
5. Marchand H. An overview of the psychology of wisdom. Prometheus Research Group;2003.

6. Shariatmadari A. The principles and philosophy of education. Tehran:Amir Kabir Publication;2017. (Persian)

7. Galinsky AD, Ku G, Wang CS. Perspective-taking and self-other overlap: Fostering social bonds and facilitating social coordination. Group Processes \& Intergroup Relations. 2005;8(2):109-124.

8. Mohaghegi H, Zoghi Paydar MR, Yaghubi A, Yar Mohammadi Vasel M, Mohammad Zadeh S. Codification and validation of a scale to measure social perspective taking. Social Cognition. 2016;5(1):20-34. (Persian)

9. Flavell JH. Theory-of-mind development: Retrospect and prospect. Merrill-Palmer Quarterly. 2004;50(3):274-290.

10. Van Der Graaff J, Branje S, De Wied M, Hawk S, Van Lier P, Meeus W. Perspective taking and empathic concern in adolescence: Gender differences in developmental changes. Developmental Psychology. 2014;50(3):881-888.

11. Long EC. Perspective-taking differences between high-and low-adjustment marriages: Implications for those in intervention. American Journal of Family Therapy. 1993;21(3):248-259. 12. Sumter SR, Bokhorst CL, Westenberg PM. The robustness of the factor structure of the Self-Restraint Scale: What does self-restraint encompass?. Journal of Research in Personality. 2008;42(4):1082-1087.

13. Brown SC. Learning across the campus: How college facilitates the development of wisdom. Journal of College Student Development, 2004;45(2):134-148.

14. Schultz D. Psychology of perfection. Khoshdel G, translator. 16th ed. Tehran:Peykan Publication;2008.

15. Zare Z. Self-inhibition and mental health based on family communication patterns [MSc Thesis]. Marvdasht:Islamic Azad University, Marvdasht Branch;2011.

16. $\mathrm{Hu} \mathrm{C}$. Measurement of wisdom among mainland Chinese [Doctoral Dissertation]. Toronto:University of Toronto;2016.

17. Arzeen S, Haq MA. An investigation of relationship between wisdom and subjective well-being for a sample of Pakistani ad- olescents. FWU Journal of Social Sciences. 2013;7(1):39-46. 18. Larrick R, Manes A, Soll J. The social psychology of the wisdom of crowds. In Krueger JI, (Editor). Fronntiers in social psychology. social judgment and decision making. New York;Psychology Press;2012. pp. 227-242.

19. LeBlanc D, Gilin DA, Calnan K, Solarz B. Perspective taking, empathy, and relational conflict at work: An investigation among participants in a workplace conflict resolution program. In International Association for Conflict Management, IACM 25th Annual Conference. 2012 Jul 11-14; Stellenbosch, South Africa;2012.

20. Opdebeeck H, Habisch A. Compassion: Chinese and western perspectives on practical wisdom in management. Journal of Management Development. 2011;30(7/8):778-788.

21. Pierra J. Investigations of enhanced relationship between philosophic mind of managers and their employees work performance in governmental organizations in Western Reserve University [PhD Dissertation]. Illinois:University of Illinois at Urbana Champaign;2009.

22. Kordnoghabi R, Nabizadeh S, Hadadi F. Investigating the role of explaining the styles of identity and religious beliefs in the construct of wisdom. Quarterly Journal of Psychology and Religion. 2017;10(1):137-154. (Persian)

23. Ghorbani R, Khormaee F. Explaining wisdom based on successful intelligence and coping self-efficacy. Journal of Developmental Psychology: Iranian Psychologists. 2016;13(49):4355. (Persian)

24. Marashi M, Sanjari H, Safaei Moqadam H, Elhampour M. The relationship between graduate students in mind, philosophical and spiritual intelligence Shahid Chamran University. Quarterly Journal of New Thoughts on Education. 2016;2(12):145-164. (Persian)

25. Ardelt M. Empirical assessment of a three-dimensional wisdom scale. Research on Aging. 2003;25(3):275-324.

26. Kord Noghabi R, Jahan F, Rashid Kh, Rezaee A. Wisdom measurement in Iran. Quarterly Journal of Educational Measurement, 2015;6(22):187-212. (Persian) 
27. Soltani I. Measuring the philosophical mentality of managers. Tadbir. 1996;7(62):16-19. (Persian)

28. Mortezaei Moghadam M. The effect of the philosophical mindfulness of managers on their decision making at Ferdowsi University of Mashhad [MSc Thesis]. Mashhad:Ferdowsi University;2001. (Persian)

29. Weinberger DA, Schwartz GE. Distress and restraint as superordinate dimensions of self-reported adjustment: A typological perspective. Journal of Personality. 1990;58(2):381-417.

30. Feldman SS, Weinberger DA. Self-restraint as a mediator of family influences on boys' delinquent behavior: A longitudinal study. Child Development. 1994;65(1):195-211.

31. Sternberg RJ. Schools should nurture wisdom. In Presseisen BZ (Editor). Teaching for intelligence. $2^{\text {nd }}$ ed. Thousand Oaks, CA:Corwin;2008. pp. 61-88.

32. Azadian S. Explanation of wisdom based on intelligence and creativity [MSc Thesis]. Hamedan:Bu-Ali Sina University;2013. (Persian)

33. Hashemi S. The study of the wisdom of the students of the humanities and basic sciences in the process of problem solving and its relations with epistemological beliefs. Quarterly Journal of New Thought on Education. 2011;7(2):53-82. (Persian)

34. Taylor M, Bates G, Webster JD. Comparing the psychometric properties of two measures of wisdom: Predicting forgiveness and psychological well-being with the Self-Assessed Wisdom Scale (SAWS) and the Three-Dimensional Wisdom Scale (3D-WS). Experimental Aging Research. 2011;37(2):129-141.
35. Ardelt M. Wisdom and life satisfaction in old age. The Journals of Gerontology Series B: Psychological Sciences and Social Sciences. 1997;52(1):15-27.

36. Holliday SG, Chandler MJ, Wisdom: Explorations in human competence. Contributions to human development. New York:Karger;1986.

37. Webster JD. An exploratory analysis of a self-assessed wisdom scale. Journal of Adult Development. 2003;10(1):13-22.

38. Smith PG. What is philosophy education?. New York:McMillan;1965. pp. 12-18

39. Gluck J, Bluck S. The MORE life experience modal: A theory of the development of personal wisdom. In Ferrari M, Weststrate NM (Editors). The scientific study of personal wisdom. New York:Springer;2014. pp. 264-295.

40. Yang SY. Wisdom and learning from important and meaningful life experiences. Journal of Adult Development. 2014;21(3):129-146.

41. Yang SY. Wisdom displayed through leadership: Exploring leadership-related wisdom. The Leadership Quarterly. 2011;22(4):616-632.

42. Brown SC. Learning across the campus: How college facilitates the development of wisdom. Journal of College Student Development. 2004;45(2):134-148.

43. Gehlbach H, Brinkworth ME, Wang MT. The social perspective taking process: What motivates individuals to take another's perspective?. Teachers College Record. 2012;114(1):197-225. 